The development which has been outlined indicates a tendency for the Branches to grow away from the Institute. If the meetings are to be occupied entirely with independent papers and discussions, what is to bind the Branches to the main organization? The enrolled students as well as Institute members receive the Procendings and the advance copies of papers, and these must be used in some way to form a bond to hold the Branches together, and to the Institute. Experience shows that as a rule the Branch meetings are not stimulated by rehearsing the New York papers and discussion. It seems advisable, therefore, that the Institute papers should be incorporated as far as possible into the text used in regular courses. Several schools are now following this practice, which must become more general if the Institute is to mean what it should to the rising generation of electrical engineers.

\section{The Advantages or Membership in the American Institute of Electrical Engineers*}

BY CHARLES B. BURLEIGH

The question has frequently been asked, what advantage is to be derived from membership in the American Institute of Electrical Engineers?

There can be no question as to the duty of every American citizen to support and maintain the Supreme Court of the United States. Can there, therefore, be advanced any legitimate reason as to why it is not a duty that he owes, not only to himself but to each and every one of his associates in the business in which he is engaged, for every electrical engineer to do his utmost to support and maintain a court of last resort, by whom all disputed technical questions in electrical engineering shall be finally settled? To assist so far as in him lies, in removing all electrical work from the region of guesswork to that of certainty, thereby increasing the stimulus to the successful investment of

* Reprinted from the Electrical Review, New York, Aug. 1, 1908. capital in electrical enterprises? To effect a concentration of effort and increased mentality excited by generous rivalry?

With these objects in view the American Institute was formed with the avowed purpose of promoting the arts and sciences connected with the production and utilization of electricity and the welfare of those employed in these industries; by means of meetings for social intercourse, the reading and discussion of professional papers, and the circulation, by means of publications among its Members and Associates, of information thus obtained.

Appreciating this situation, affiliation with the organization is not a question of what benefit will result to the individual, but is a duty he owes to the art, to his associates and to himself, to do everything in his power to aid and assist in the support and maintenance of an institution without which we would all be whirling around in our own little circle, duplicating effort, narrowing the scope of the art and our own fields of usefulness.

The electrical engineer also owes a duty to the public in general, who place in his hands the solving of problems in connection with the details of which they are totally uniformed, and only by placing himself in a position to give them the best information procurable can he be assured of rendering to them full return for the confidence imposed. Again, it is generally conceded by the world at large that the most valuable opinion and judgment on any class of work is that rendered by the leaders in that profession; for which reason the electrical engineer's standing is in a great measure fixed by the recognition of his ability by his associates, and only by an acquaintance with them, thus offering them the opportunity to familiarize themselves with his capabilities, can he establish his standing, and as the best estimate of an engineer as a man and an engineer is the opinion of the members of his own profession, it is his duty to himself, as well as to 
those from whom he derives his livelihood, that he become known to and acquainted with his associates.

The benefits to be derived from this association depend largely upon the individual to the extent that if he joins the organization, prompted only by selfish motives, to receive and not to impart benefit, he will receive but little, while he who connects himself with the association, hoping by his work to promote its success, receives in return inestimable benefit from the fact that his work and his contributions tend to make him known to his associates and establish his standing not only among them but in the field at large.

Again, in connection with the different matters brought before the organization for its consideration, he either attends the meeting at which they are presented or reads of them in the TRANSACTIONS, and as reading any similar article presented through the usual channels, forms his own opinions on the subjects treated, but his connection with this association offers him the opportunity to familiarize himself with the opinions of his associates on the subject, and by discussing their opinions, either with them or with himself, arrives at a much broader understanding of the matter.

As the association aims to take up and discuss in its earlier stages of development any and all improvements in the art, the facilities offered enable the membership to keep just a little ahead of the non-members and the public, and prepares them to pass judgment on new devices as soon as their practical consideration becomes desirable.

The scope of the art is continually broadening to such an extent that the necessity for specialization is becoming more and more apparent. The closer the lines are drawn in this direction the more important becomes an organization which offers us the facilities for keeping in touch with the whole general situation, and the more good work can the specialist do for the organization and through it for the art.

Having been connected with the electrical business for some thirty years and with the Institute seventeen years, I feel that I may be pardoned for a suggestion to the older members and a word of advice to the younger members of the profession.

To the older members I would say: You have seen our profession grow in the last thirty years from the electrician who could set up the gravity cell for the operation of the key and sounder, to the electrical engineer who can carry on his shoulders the water and steam power of the world and deliver its useful energy at any point where commercial conditions make its utilization desirable, outstripping by leaps and bounds all other engineering professions. I may have, contributed individually no more than you to this marvelous development, but the association of whici I am a member is in a great measure responsible for it, for which reason you owe to it in a large measure the benefit you have and are receiving from it. You would be ashamed to be accused of not paying your just debts. Here is one long overdue, and the quicker you settle by adding your assistance to the good work in becoming a member the sooner you can look everybody in the face and say, "I am in part responsible for the result attained."

To the neophyte I would say:

In any line, individual effort is always praiseworthy, but team work presents the shortest route to success. The sooner you connect yourself with the Institute the quicker you will begin to obtain the best returns from the energy you expend in promoting the interests of the profession you have entered, to the benefit of your employer and to yourself, and if you remain in the business you can look back with pride, in the years to come, to the fact that you have always, from the first moment of entering the profession, lent your best efforts to the best advantage to the advancement of the art. 
You may feel that you have completed your education and are now about to reap the benefits. Allow me to disabuse your mind of this idea. Your education has just commenced. Your school and college have provided you with an excellent outfit of tools and you are now about to be taught how to use them to the best advantage. The art is progressing and you will find that new adaptations require new tools not in your chest, and membership in the Institute will tend to keep your tool chest up to date.

\section{Sections and Branches}

At a meeting of the Board of Directors on August 14, 1908, authority was granted to the Members and Associates of the Institute at Fort Wayne, Indiana, to establish the Fort Wayne Section, with Mr. E. A. Wagner chairman, and Mr. M. J. Kehoe as, secretary.

\section{Minnesota Section}

At the regular monthly meeting of the Minnesota Section held at the office of the St. Paul Gas Light Company on the evening of June 1, 1908, the secretary being absent, Mr. Hibbard was appointed secretary pro tem by the chairman. The report of the Committee on Membership was received and read by the secretary, and was as follows:

The committee appointed by the Minnesota Section of the American Institute of Electrical Engineers, to consider the resolutions on the subject of Institute membership, adopted by the Toronto Section, on the 20th of February, 1908, after due consideration of the fact that the requirements for transfer to the grade of Member are extremely rigid and also the fact that the requirements for the grade of Associate are now easy to attain, reports as follows:

The matter of the classification of membership is an important one and deserves consideration.

We heartily endorse the resolution of the Toronto Section.

We suggest that the third classification should have a more distinctive name than that adopted by the Toronto Section.

A motion to accept the report of the committee and to continue the work was carried, it being considered desirable to have this committee carry the work through according to their report, and to take such steps as are necessary to bring about the proposed change in Article II of the Constitution.

The report of the Committee on ByLaws was then read by Mr. Dibble, chairman.

There being no further business to come before the meeting, the discussion of the Institute papers by Messrs. Vaughan and Neall on lightning protection was taken up.

\section{San Francisco Section}

At a meeting of this Section on June 26,1908 , seventy members and guests heard Mr. C. F. Elwell read a paper entitled "Reduction of Iron Ores by Electricity."

\section{St. Louis Section}

On April 8, 1908, sixty-three members and guests attended a meeting of the St. Louis Section at the Engineer's Club. There was a discussion on the advisability of an Institute intermediate grade of membership, followed by the presentation and discussion of a paper by Mr. E. D. Smith, entitled "Power Generating and Distributing Systems of the United Railways of St. Louis."

Another meeting of this Section, attended by forty-nine members and guests, was held at the Ashley Street plant of the Union Electric Light and Power Company on May 16, 1908. By courtesy of the officials of the light and power company, the entire plant was thrown open for inspection.

\section{Kansas Agricultural College}

At a meeting of this Branch, at Manhattan, Kansas, on June 3, 1908, Mr. W. L. Enfield was re-elected chairman and Mr. W. C. Lane elected secretary to serve until June, 1909. 